\title{
Analysis of Habit Patterns in Academic Behavior in Student Learning Discussions
}

\section{Maulida Noor Mila Zulfa1, Deka Setiawan², Much Arsyad Fardani}

${ }^{123}$ Program studi guru sekolah dasar, Universitas Muria Kudus, Indonesia

\author{
ARTICLEINFO \\ Article history: \\ Received 2 Juni 2020 \\ Received in revised form \\ 12 Juli 2020 \\ Accepted 10 Agustus 2020 \\ Available online 28 Agustus \\ 2020 \\ kata kunci: \\ Perilaku Akademik dan \\ Diskusi Pembelajaran \\ keywords: \\ Academic Behavior and \\ Learning Discussion
}

\begin{abstract}
A B S T R A K
Metode diskusi dapat mendorong siswa yang tidak aktif menjadi aktif dan percaya diri tetapi masih terdapat beberapa siswa yang belum dapat berkerjasama dengan baik. Penelitian ini bertujuan untuk menganalisis pola kebiasaan perilaku akademik pada diskusi pembelajaran siswa kelas 4 . Populasi pada penelitian ini adalah seluruh siswa kelas 4 di SD 5 Karangbener berjumlah 24 siswa yang meliputi 15 perempuan dan 9 lakilaki. Penelitian ini menggunakan teknik pengumpulan data meliputi tahap observasi, wawancara dan catatan lapangan. Penelitian ini menggunakan metode analisis data deskriptif kualitatif. Hasil analisis terhadap perilaku akademik siswa selama diskusi pembelajaran yaitu klasifikasi perilaku siswa saat berdiskusi diantaranya berdoa sebelum pelajaran dimulai, memperhatikan penjelasan guru, membuat ringkasan materi, tepat waktu dalam mengerjakan tugas, ikut berpartisipasi dalam diskusi, berani mengungkapkan pendapat, menghargai pendapat siswa lain, menulis hasil diskusi, menyampaikan hasil diskusi dengan percaya diri, rajin membaca,
\end{abstract} semangat dalam mengikuti pembelajaran, konsentrasi saat pembelajaran berlangsung, rajin mengerjakan latihan soal, berani bertanya ketika mendapatkan kesulitan saat mengerjakan latihan soal. Perilaku akademik siswa kelas IV SD 5 Karangbener termasuk dalam interprestasi sangat baik dengan indikator perilaku yang telah ditemukan berdasarkan data lapangan. Metode diskusi memberikan dampak positif akademik siswa yang dapat ditinjau dari ranah kognitif, afektif, dan psikomotorik.

\begin{abstract}
A B S T R A C T
The discussion method can encourage inactive students to be active and confident, but there are still some students who are not able to cooperate well. This study aimed to analyze the pattern of academic behavior habits in the learning discussion of grade 4 students. The population in this study was all grade 4 students at SD 5 Karangbener totaling 24 students including 15 girls and 9 boys. This research used data collection techniques including the stages of observation, interviews and field notes. This study used descriptive qualitative data analysis method. The results of the analysis of students 'academic behavior during the learning discussion were the classification of student behavior during discussion including praying before the lesson began, paying attention to the teacher's explanation, making material summaries, being on time in doing assignments, participating in discussions, daring to express opinions, respecting other students' opinions, writing the results of the discussion, conveying the results of the discussion confidently, reading diligently, enthusiastically taking part in learning, concentration during the learning process, diligently working on the exercises, daring to ask questions while having difficulty doing the exercises. The academic behavior of fourth grade students of SD 5 Karangbener was included in very good interpretations with behavioral indicators that have been found based on field data. The discussion method has a positive academic impact on students which can be viewed from the cognitive, affective, and psychomotor domains.
\end{abstract}

\section{Introduction}

Indonesia implements educational reforms and innovations through the development of the 2013 curriculum. The 2013 curriculum applied in Indonesian education is translated into educational practices by taking into account the global context and the plurality of Indonesian society. The mission and orientation of the 2013 curriculum have specific goals so that students have the competencies needed for social life in the present and the future. Learning in the 2013 curriculum is carried out using a scientific approach that is oriented towards student centered learning, namely student-centered learning. To improve the quality of education, there are several important

Copyright (C) Universitas Pendidikan Ganesha. All rights reserved.

${ }^{1}$ Corresponding author

E-mail addresses: 201633234@std.umk.ac.id ${ }^{1}$ (Zulfa), deka.setiawan@umk.ac.id ${ }^{2}$ (Setiawan), arsyad.fardani@umk.ac.id ${ }^{3}$ (Fardani). 
components that must be fulfilled, including teachers, students, facilities and infrastructure, quality of educators and innovative learning models in the teaching process and curriculum development (Amadah, Setiawan, \& Ardianti, 2020; Jailani, 2017). To be able to teach well, teachers must master pedagogical theory and practice well, such as understanding the character of students, being able to explain subject matter well, being able to provide an evaluation of what has been taught, being able to develop the potential of students, because this can make teachers skilled in carrying out daily teaching tasks Imelda (2020). Teachers must have many variations of learning methods that can develop students' thinking skills because learning methods are a very important component to determine the success or failure of a learning process (Jayanti \& Ariawan, 2018; Sabri, 2005).

Currently, many students feel bored in learning because teachers only use conventional methods. Students only tend to accept teacher delivery so that students become passive. If student learning is not active, the learning process does not run optimally (Anika \& Fajar, 2020; Ikmah, Maryadi, \& Wijayanti, 2018). If the active learning process will make students motivated in learning, learning objectives can be achieved optimally. One method that makes students active in learning is the discussion method. The discussion method is the teacher's method of giving problems to students and students are given the opportunity to solve these problems. This method is a method that exposes students to a problem so that it can improve students' critical thinking. This method encourages students to be actively involved in learning. The lecture method also invites students to think systematically about the problem to be solved (Sari, Mardhiati, \& Khutobah, 2014; Supriyati, 2020). By discussing, students can receive, exchange information and defend their opinions in solving problems. Research conducted by Sari et al. (2014) also stated that the discussion method can improve student learning outcomes so that it has a positive impact on learning outcomes.

This is supported by the results of observations made at one elementary school. Based on the results of interviews conducted with homeroom teachers of grade 4 SD 5 Karangbener on November 20,2019 , the method that is often used is the discussion method because indirectly the discussion method can shape students' behavior and emotions. Discussion allows students to think critically by solving a problem in groups that have various kinds of opinions so that students can learn to respect the opinions of others. Familiarize students with listening to other people's opinions even if they differ from their own opinions is a way of getting students used to being tolerant Djamarah (2015). The results of the interviews that have been conducted showed that the discussion method can encourage inactive students to become active and students who are quiet and lack confidence to be brave in expressing their opinions. However, there are still some students who tend not to be able to carry out learning discussions properly because they have not been able to control their emotions properly either. During the learning discussion process, these students were not able to collaborate well with their group of friends. There are even gaps between group members who actually contribute to completing the discussion task with group members who only list their names without contributing to the discussion. Teachers must be able to arouse students' enthusiasm for learning, and promote the elaboration process so that the behavior of students who want to be measured can be seen and appear during the learning process by taking the principles of active students (Huda \& Yulianti, 2020; Sitasih, 2020). On the other hand, there are several groups that can have good discussions with the existence of a clear division of tasks and a balanced contribution among group members so that group assignments are well resolved. This can be overcome by the way the teacher changes group members, in addition to making students get to know each other with their classmates, this method intends to combine students who have high, medium and low intelligence levels so that they can exchange opinions and get new knowledge from friends. a bunch of them. This makes students who initially could not become capable, who do not understand to understand, who are not active become active so as to improve student learning outcomes. Therefore, it can be seen that students' academic behavior influences the learning discussion process in class.

Research conducted by Imran, Harun, \& Sumarni (2015) regarding the application of the discussion method to improve learning outcomes shows that the percentage of classical learning completeness before implementing the discussion method is $20 \%$, in the first cycle it increases to $60 \%$ and the second cycle increases to $80 \%$ so that it can be seen that the application of the discussion method can improve the learning outcomes of fourth grade students Toraranga Small Elementary School. Research conducted by Prianto \& Puji (2017) also shows that the use of the discussion method has an effect on learning outcomes which has increased by 10.77 points from the initial 72.01 to 82.78 and has reached the KKM. Research conducted by Susarno (2011) shows that the implementation of BLP has a positive influence on students and an increase in student academic behavior. Research conducted by Rahayu, Nuraedah, \& Jamaludin (2016) also shows that the discussion method can improve student learning outcomes. Based on this description, it can be 
concluded that the discussion method can improve learning outcomes, but there are still some students who tend not to be able to carry out learning discussions properly because they have not been able to control their emotions well too.

Based on this explanation, the research objective was formulated, namely to analyze the pattern of academic behavior habits in the learning discussion of the fourth-grade students of SD 5 Karangbener which consisted of 24 students by taking the subject of students and class teachers. The study was conducted by observing the learning process in grade IV SD 5 Karangbener which used the discussion method by forming groups based on seating positions determined by the class teacher and taking place systematically. Before the discussion process begins, the teacher delivers some material which will be used as a discussion topic. The discussion method is expected to have a positive impact on students so that it can improve student learning outcomes.

\section{Research Method}

This type of study was conducted using a qualitative approach. This study was conducted by observing the discussion method used in learning and students' academic behavior in learning discussion activities. The subjects in this study were fourth grade students consisting of 24 students including 15 girls and 9 boys. Observations were made on November 20, 2019, then for research carried out on March 17, 2020.

This study used a qualitative approach that used 3 stages including; (1) Orientation or Description Stage. At this stage, researchers obtained data from observations and information from interviews with teachers and grade 4 students regarding the methods used in learning and students' academic behavior in learning discussion activities; (2) The Reduction or Focus Stage. At this stage, the researcher selected useful, interesting and important data that has been obtained from the first stage, which could then be used as the research focus; (3) Selection Stage. At this stage, the researcher conducted an analysis on the research focus through the data and information that has been obtained into new knowledge.

The data collection technique in this study was carried out by interviewing the fourth grade teacher and 5 students who were the group leaders to conduct a preliminary study to find patterns of academic behavior habits to be studied, then continued with observation techniques, where the researcher made observations about several related things, obtaining data on students' academic behavior habits was done using participant observation. To strengthen the data, the researcher provided documentation data in the form of observation sheet data, photos of the learning discussion process, and photos of interview activities. After observing the learning activities, the researcher recorded important things which were then analyzed and linked to other data.

Data analysis techniques in qualitative research, data obtained from various sources, using various techniques (triangulation) and carried out continuously to completion. The data that has been obtained is then summarized, focusing on important things. Thus, the data that has been reduced will provide a clear picture, and make it easier for researchers to carry out further data collection. After the data is reduced, the next step is to display the data. In qualitative research, data presentation can be done in the form of a short description or narrative in nature. The third step in qualitative data analysis is drawing conclusions and verification.

\section{Result and Discussion}

Based on the results of observations made by the researcher, it showed that learning in grade IV SD 5 Karangbener used the discussion method by forming groups based on seating positions and determined by the class teacher and took place systematically. Before the discussion process began, the teacher delivered some material which would be used as a discussion topic. It aimed to make it easier for students to complete assignments. Before giving the assignment, the teacher explained the flow of the discussion. Students were allowed to search for sources of information from books and worksheets. In working on group assignments, students were given a time limit of 25 minutes. It was seen that the division of tasks was very good for each group member, namely looking for information and recording information so that the task could be completed on time or even faster than the predetermined time. After completing the assignment, each group was asked to present the results of the discussion in front of the class randomly, according to a small roll of paper with the name of the group taken by the teacher which aimed to increase students' self-confidence to speak in public and encourage students to develop his potential. Other groups were allowed to ask questions or argue. Then the teacher perfected the results of the discussion from the group. The teacher 
appreciated students by giving star points. The implementation of discussions led by teachers and students discussions based on material provided by the teacher. Based on the results of interviews with teachers, it is known that the method of discussion carried out by the teacher is one of the simple methods to actively involve students in learning. This is in accordance with the theory presented by (Imran et al., 2015; Supriyati, 2020) stated that the discussion method is defined as a strategy to convey learning material that involves students actively discussing and finding alternative solutions to a discussion topic.

During the discussion, students seemed very active and seemed very happy to participate in learning discussions without the slightest pressure and coercion. Each student can participate in the discussion well. Students are active in discussing discussion topics so that the class conditions are a bit crowded. The group leader can coordinate the members well, by dividing the task force and allocating time appropriately. Students show tolerant behavior by accepting and responding well to the results of other group discussions. The discussion that is carried out basically has the aim of encouraging students to solve problems to make conclusions which are then reinforced by the teacher. So that students can develop the potential that students have. The method implemented is the application of the cooperative learning model, which is a teaching and learning process that involves the use of small groups that allow students to work together in order to maximize their own learning and cooperative learning emphasizes cooperation between students (Hamalik, 2015; Krisdayati \& Kusmariyatni, 2020). Learning discussions are basically carried out with the aim of encouraging students to find their own problem solutions so that they can make conclusions that are reinforced by the teacher. So that students can develop their potential. A curriculum that is believed to be good is one that can provide broad freedom for students to ask questions, conduct searches and draw their own conclusions (Sadulloh, 2003; Shoimin, 2014).

Based on the research results, it is known that the implementation of the discussions carried out was in accordance with the principles of discussion and was carried out systematically. The results of the research conducted by researchers with student informants showed that there were five students, namely NR, FPP, MKA, DM and MBDA who admitted that in their daily learning they often used the discussion method. Researchers classify student responses into several indicators. The interpretation of student behavior based on the results of student assessments of peers is as follows.

Table 2. Interpretation of Student Academic Behavior in Learning Discussions

\begin{tabular}{|c|c|c|c|}
\hline NO & Academic Behavior Indicators & $\begin{array}{c}\begin{array}{c}\text { Percentage of Total Per } \\
\text { Indicator }\end{array} \\
\end{array}$ & $\begin{array}{c}\text { Score } \\
\text { Interpretation }\end{array}$ \\
\hline & Pray before the lesson starts & $100 \%$ & Very good \\
\hline 2. & $\begin{array}{l}\text { Pay attention to the teacher's } \\
\text { explanation }\end{array}$ & $100 \%$ & Very good \\
\hline & Make a summary of the material & $87,5 \%$ & Very good \\
\hline 4 & Be on time for assignments & $91,6 \%$ & Very good \\
\hline & Participate in discussions & $95,8 \%$ & Very good \\
\hline 6 & Dare to express opinions & $74,1 \%$ & Well \\
\hline 7. & Respect other students' opinions & $100 \%$ & Very good \\
\hline 8. & Write the results of the discussion & $95,8 \%$ & Very good \\
\hline 9. & $\begin{array}{l}\text { Deliver the results of the discussion } \\
\text { confidently }\end{array}$ & $87,5 \%$ & Very good \\
\hline 10. & Read diligently & $83,3 \%$ & Very good \\
\hline 11. & Passion for learning & $95,8 \%$ & Very good \\
\hline 12. & Concentration when learning takes place & $91,6 \%$ & Very good \\
\hline 13. & Diligently doing practice questions & $70,8 \%$ & Well \\
\hline 14. & $\begin{array}{l}\text { Dare to ask when having trouble doing } \\
\text { practice questions }\end{array}$ & $83,3 \%$ & Very good \\
\hline
\end{tabular}


Based on the table above, praying before the lesson starts has a $100 \%$ percentage, which means that all students do prayer together by reading Asmaul Husna every day before the lesson starts. Paying attention to the explanation from the teacher has a presentation of $100 \%$ very good interpretation which means that all students always pay attention to the teacher's explanation very well. Making material summaries has a percentage of $87.5 \%$ of very good interpretations, which means that only 21 students make material summaries using their own language, and 3 other students do not make a summary of the material matters. The three students are MSN, MAF and MIAN. MSN explained that the material did not need to be recorded again because the material was already available in the book, while MAF stated that he had remembered the teacher's explanation without re-writing it, and MIAN stated that he felt lazy to make his own summary, he chose to borrow the summary that had been made. by his friend if he is going to do daily tests, the Mid-Semester Examination and the Final Semester Examination. Being on time in doing assignments has a percentage of $91.6 \%$ of very good interpretations, which means that as many as 22 students can share their time very well in completing group assignments. Participating in the discussion had a very good percentage of $95.8 \%$ of the interpretation, which means that from 24 students only 1 student did not participate in participating in the learning discussion properly, even an informant who was an Indonesian citizen explained that she often did not go to school, even if she went to school. at the time of learning after the second break he went home without the knowledge of the Indonesian citizen. Dare to express opinions have a percentage of $74.1 \%$ good interpretation, meaning that as many as 19 students can express opinions confidently while 5 other students still feel less confident. The informants of Indonesian Indonesian mothers stated that the reason why students were not confident in their opinion was that they felt afraid if the answer was wrong and would be laughed at by their friends, even though it was only their concern, even though sometimes it did happen that the Indonesian citizen would reprimand him, he always gave support and train them to be confident in expressing their opinions.

Respecting the opinions of other students has a very good presentation of $100 \%$ interpretation, which means that all students always listen to other people's opinions well, if there is a difference in opinion the teacher provides opportunities for other students to argue, and the teacher's job is to clarify suggestions or opinions which then provide conclusions. An Indonesian citizen informant stated that she always instills in students to always respect other people's opinions so that there are no disputes. Writing the results of the discussion has a percentage of very good interpretations of $95.8 \%$, meaning that from 24 students only 1 student did not write the results of the discussion. Delivering the results of the discussion with confidence has a percentage of $87.5 \%$ very good interpretation, which means that as many as 21 students can convey the results of the discussion confidently and 3 students have not been able to convey the results of the discussion confidently. Diligent reading has a percentage of $83.3 \%$ of very good interpretations, which means that 24 students have the habit of reading before the lesson begins which is also called literacy. 4 other students prefer to play than read. The Indonesian citizen informant stated that to increase students' reading interest, he advised students to find sources of information from books in the library at least 2 books to complete discussion assignments.

The enthusiasm in participating in learning has a percentage of $95.8 \%$ very good interpretations, which means that out of 24 students only 1 student is less enthusiastic in participating in learning activities. Concentration when learning takes place has a very good presentation of $91.6 \%$, meaning that 22 students can concentrate very well while learning is taking place, and 2 other students tend to talk to themselves outside the topic of discussion, play with whatever objects are in front of them, often come out enter the classroom and walk around in the classroom. To overcome this the teacher always gives points as punishment, the more points the heavier the punishment. Diligently working on question exercises has a percentage of $70.8 \%$ good interpretation meaning that 17 students always work on the questions on the Student Worksheet and 7 other students prefer to cheat. Students prefer to do the worksheets at home first before the teacher gives orders. Dare to ask questions when having difficulty doing practice questions has a percentage of $83.3 \%$ and very good interpretation. If students find questions that are difficult, students are not ashamed to ask their friends or teachers, then they will discuss them together. Therefore, it can be concluded that students' academic behavior is included in very good interpretations with behavioral indicators that have been found based on field data.

There were several other behaviors carried out by students that were different from the classification. The behavior found during this discussion is behavior that occurs because it is influenced by the environment and student psychology. Students who have behavior that tend to be shy arise because they think that the answers submitted are wrong and will be laughed at by other 
friends. So that made him afraid and less confident in expressing his opinion. As in Field Theory in (Mbatha, 2015) which assumes that everyone has a certain living space which is the real factors that influence individual behavior. The behavior shown by students during the learning discussion includes good behavior and bad behavior. Bad behavior is influenced by the lack of readiness of students in learning. The same thing was conveyed by (Pribadi, 2017; Rusman, 2017) which states that learning is a change in behavior where the change can lead to good behavior, but there is also the possibility of leading to worse behavior, because learning involves various aspects of personality, physical and psychological.

Other behaviors such as self-confidence to express opinions and participate in learning discussions are also influenced by the environment that supports students to freely express their opinions. Research conducted by (Kelirik, 2018; Pauziah, 2017) also stated that proven discussion methods increase self-confidence and courage in expressing opinions. Student participation increases if the surrounding environment supports students to actively participate, students will form active behavior, for example the teacher asks one group to read the results of the discussion then other groups are asked to respond to this can be done to make students actively participate in learning discussions. Apart from environmental factors, behavior is also influenced by student psychological factors. In the field, students show some excessive behavior, for example when the answer is correct, the students will cheer with joy, which in turn makes the class crowded. This is related to student psychology in controlling student emotional.

There are several negative behaviors in students including laziness to do practice questions and preferring to cheat, lazy to note important things, go home early without the knowledge of the teacher, and often don't go to school. This is influenced by psychology in students' emotional control where students have not been able to motivate and encourage themselves to be better. Based on the description above, it can be concluded that the factors that influence the habitual pattern of academic behavior are the environment and psychology in emotional control.

\section{Conclusion}

In accordance with the findings of the data, there are several classifications of student behavior during discussion including praying before the lesson began, paying attention to the teacher's explanation, making material summaries, being on time in doing assignments, participating in discussions, daring to express opinions, respecting other students' opinions, writing discussion results, conveys the results of the discussion with confidence, reads diligently, is enthusiastic in participating in learning, concentrates when the learning is taking place, is diligent in doing practice questions, dares to ask questions when having difficulties while doing practice questions. The academic behavior of fourth grade students of SD 5 Karangbener is included in very good interpretations with behavioral indicators that have been found based on field data. Thus it can be concluded that the discussion method has a positive academic impact on students which can be viewed from the cognitive, affective, and psychomotor domains.

\section{References}

Amadah, Setiawan, \& Ardianti. (2020). Peningkatan Hasil Belajar Siswa Kelas IV Melalui Model Think Pair Share Berbantuan Media Puzzle. Jurnal Edubasic, 2(1). https://ejournal.upi.edu/index.php/edubasic/article/view/27010

Anika, \& Fajar. (2020). Efektivitas Model Pembelajaran Kooperatif Tipe Make-A Match Dalam Meningkatkan Kompetensi Sikap Siswa Dan Kompetensi Pengetahuan Siswa Pada Pelajaran IPS. Jurnal Ilmiah Sekolah Dasar, 4(1), 80-85. http://dx.doi.org/10.23887/jisd.v4i1.24047

Djamarah. (2015). Stratrgi Belajar Mengajar. Jakarta: Rineka Cipta.

Hamalik, O. (2015). Proses Belajar Mengajar. Jakarta: .

Huda, F. A., \& Yulianti, I. (2020). Upaya Meningkatkan Motivasi Dan Hasil Belajar Siswa Menggunakan Model Cooperative Learning Tipe Rotating Trio Exchange ( Rte) Motivasi Belajar , Hasil Belajar Cooperative Learning (Rte ). 1, 21-26. https://doi.org/10.31932/jutech.v1i1.691

Ikmah, F., Maryadi, \& Wijayanti, A. (2018). Pengaruh Model Pembelajaran Open Ended Problem Berbantu Media Kalkulator Dakon (Kakon) Terhadap Hasil Belajar Matematika Siswa Kelas Ii Sdn Sambiroto $01 \mathrm{Kec}$ Tembalang Kota Semarang. 2(3), 126-133. 
https://doi.org/10.24114/jgk.v2i3.10394

Imelda. (2020). Meningkatkan Kemampuan Guru Melaksanakan Proses Pembelajaran Dengan Adanya Supervisi Klinis. Jurnal Ilmiah Sekolah Dasar, 4(1). http://dx.doi.org/10.23887/jisd.v4i2.25444

Imran, Harun, \& Sumarni. (2015). Penerapan Metode Diskusi Untuk Meningkatkan Hasil Belajar Siswa Kelas IV Sekolah Dasar Kecil Torarnga Pada Mata Pelajran Pkn Pokok Bahasan Sistem Pemerintahan Kabupaten, Dan Provinsi. Jurnal Kreatif Tadulako Online, 3(4). http://jurnal.untad.ac.id/jurnal/index.php/JKTO/article/view/3063

Jailani. (2017). Penggunaan Peta Konsep Untuk Belajar Bermakna Dan Peningkatan Pemahaman Siswa Dalam Pembelajaran Biologi. Jurnal Biology Education, 6(1), 30-40. Https://Doi.Org/10.1017/CB09781107415324.004

Jayanti, Y., \& Ariawan, V. A. N. (2018). Implementasi Model Experiential Learning Untuk Meningkatkan Keterampilan Menulis Karangan Narasi Siswa Sekolah Dasar. Muallimuna: Jurnal Madrasah Ibtidaiyah. Https://Doi.Org/10.31602/Muallimuna.V4i1.1442

Kelirik, N. (2018). Penerapan Metode Diskusi Kelompok untuk Meningkatkan Hasil Belajar Ipa Di Sekolah Dasar Negeri 1 Sukadana. Jurnal IKA, 16(1). http://dx.doi.org/10.23887/ika.v16i1.19821

Krisdayati, \& Kusmariyatni. (2020). Model Pembelajaran Kooperatif Tipe Make A Match Terhadap Minat Baca. Mimbar PGSD Undiksha, 8(2), 156-159. Retrieved From Https://Ejournal.Undiksha.Ac.Id/Index.Php/JJPGSD/Article/View/24935/15605

Mbatha, B. (2015). A Paradigm Shift: Adoption Of Disruptive Learning Innovations In An ODL Environment: The Case Of The University Of South Africa. International Review Of Research In Open And Distributed Learning, 16(3), 218-232. https://www.erudit.org/en/journals/irrodl/1900-v1-n1-irrodl04980/1065980ar/abstract/

Pauziah, R. (2017). Penerapan Metode Diskusi Untuk Meningkatkan Aktivitas Siswapada Pembelajaran Menirukan Pembacaan Pantun Anakdi Kelas Iv Sd Negeri 19 Kepahiang Kabupaten Kepahiang Provinsi Bengkulu. Jurnal PGSD: Jurnal Ilmiah Pendidikan Guru Sekolah Dasar, 10(1), 42-46. Retrieved From Https://Ejournal.Unib.Ac.Id/Index.Php/Pgsd/Article/View/2970/1458.

Prianto, \& Puji, T. (2017). Metode Diskusi Macromedia Flash Untuk Peningkatan Hasil Belajar Alat Ukur Mekanik. Jurnal Taman Vokasi, 5(1). https://dx.doi.org/10.30738/jtv.v5i1.1427

Pribadi, R. B. A. (2017). Media Dan Teknologi Dalam Pembelajaran. In Jakarta: Kencana.

Rahayu, Nuraedah, \& Jamaludin. (2016). Upaya Meningkatkan Hasil Belajar Siswa Pada Mata Pelajaran IPS Melalui Metode Diskusi Kelompok Pada Siswa Kelas IV SDK Siendeng Kecamatan Bolano Lambunu. Jurnal Kreatif Tadulako, 4(5). https://www.neliti.com/publications/108243/upaya-meningkatkan-hasil-belajar-siswapada-mata-pelajaran-ips-melalui-metode-di

Rusman. (2017). Belajar Dan Pembelajaran Berorientasi Standar Proses Pendidikan. Jakarta: Kencana.

Sabri. (2005). Strategi Belajar Mengajar Dan Micro Teaching. Jakarta: Quantu Teaching.

Sadulloh, U. (2003). Pengantar Filsafat Pendidikan. Bandung: Alfabeta.

Sari, Mardhiati, \& Khutobah. (2014). Penerapan Metode Diskusi dengan Menggunakan Media Gambar Untuk Meningkatkan Aktivitas Dan Hasil Belajar Siswa Kelas III Dalam Pembelajaran Pkn Tema Lingkungan di SDN Sumberlesung 02 Ledokombo Jember. Jurnal Edukasi UNEJ, 1(2), 36-39. Retrieved From Https://Jurnal.Unej.Ac.Id/Index.Php/JEUJ/Article/View/1399/1146.

Shoimin. (2014). Model Pembelajaran Inovatif Dalam Kurikulum 2013. Yogyakarta: Ar-Ruzz Media.

Sitasih, D. K. (2020). Supervisi Akademik Untuk Meningkatka Kompetensi Guru Dalam Proses Pembelajaran Di SD. Jurnal Ilmiah Sekolah Dasar, 4(1). http://dx.doi.org/10.23887/jisd.v4i2.25461

Supriyati, I. (2020). Penerapan Metode Diskusi Dalam Pembelajaran Keterampilan Berbicara Pada Siswa Kelas VIII MTSN 4 Palu. Jurnal Bahasa Dan Sastra, 5(1), 104-116. 
https://core.ac.uk/download/pdf/289713771.pdf.

Susarno. (2011). Pengaruh Penerapan Building Learning Power (BLP) Terhadap Perilaku Akademik Di SMP Negeri 1 Sidoarjo. Junal Mahasiswa Teknologi Pendidikan, 1(1). https://jurnalmahasiswa.unesa.ac.id/index.php/jmtp/index 